\title{
Pola Penurunan Viabilitas dan Pengembangan Metode Pendugaan Vigor Daya Simpan Benih Pepaya (Carica Papaya L.)
}

\author{
Viability Deterioration Pattern and Storability Estimation Method of Papaya \\ (Carica papaya L.) Seeds
}

\author{
Astryani Rosyad ${ }^{1}$, M. Rahmad Suhartanto ${ }^{2,3^{*}}$, dan Abdul Qadir ${ }^{3}$
}

Diterima 4 Agustus 2016/Disetujui 26 Oktober 2016

\begin{abstract}
Information of seed quality during storage can be determined through the actual storage and storability vigor estimation. This study aimed at comparing effective accelerated aging method between physical and chemical, and studying the seed deterioration during storage in ambient $(T$ $\left.=28-30{ }^{\circ} \mathrm{C}, \mathrm{RH}=75-78 \%\right)$ and $\mathrm{AC}\left(\mathrm{T}=18-20^{\circ} \mathrm{C}, \mathrm{RH}=51-60 \%\right)$ condition with three levels of initial moisture content $(8-10 \%, 10-12 \%$, and 12-14\%) for 20 weeks. The final objective of this research was to develop model for storability vigor of papaya seed. Two experiments, accelerated aging and seed storage were conducted at Seed Laboratory, Department of Agronomy and Horticulture, Bogor Agricultural University from October 2015 to May 2016. A completely randomized design with nested factors and four replications was applied to both experiments. The results showed that physical accelerated aging using IPB 77-1 MMM machine was more effective than chemical accelerated aging using IPB 77-1 MM machine for papaya seed. The viability of seed stored in AC condition remained high until the end of the storage period, whereas it declined at 16 week storage period in the ambient condition. The viability of seed with initial moisture content of $12-14 \%$ declined faster than that of initial moisture content of 8-10\% after 18 week storage periode. The model used to estimate the storability vigor of papaya seed accurately was the equation $y=a+b$ $\exp ^{c x}$ where $y:$ storability vigor estimation, $x:$ aging time and $a, b, c:$ constant value. Simulation of storability vigor estimation with constant value of $a, b, c$ and input of aging time can estimate storability seed vigor in actual storage.
\end{abstract}

Keywords: accelerated aging, IPB 77-1 MM machine, IPB 77-1 MMM machine, seed storage, simulation

\footnotetext{
ABSTRAK

Informasi mutu benih selama penyimpanan dapat diketahui melalui penyimpanan secara aktual dan pendugaan vigor daya simpan. Penelitian ini bertujuan untuk membandingkan metode pengusangan cepat yang efektif antara fisik dengan kimia serta mempelajari pola penurunan viabilitas benih selama penyimpanan aktual pada kondisi simpan kamar (suhu $=28-30{ }^{\circ} \mathrm{C}, \mathrm{RH}=75$ $78 \%$ ) dan $\mathrm{AC}$ ( $\left.\mathrm{suhu}=18-20^{\circ} \mathrm{C}, \mathrm{RH}=51-60 \%\right)$ dengan tiga tingkat kadar air awal $(8-10 \%, 10-12 \%$, dan $12-14 \%$ ) selama 20 minggu. Tujuan akhirnya adalah membangun model vigor daya simpan benih pepaya. Penelitian pengusangan cepat dan penyimpanan dilakukan pada bulan Oktober 2015 sampai Mei 2016 di Laboratorium Benih, Departemen Agronomi dan Hortikultura, Institut Pertanian Bogor. Kedua penelitian menggunakan rancangan acak lengkap tersarang dengan empat ulangan. Hasil penelitian menunjukkan bahwa pengusangan cepat secara fisik dengan alat IPB 77-1 MMM lebih efektif daripada pengusangan kimia dengan alat IPB 77-1 MM untuk benih pepaya. Viabilitas benih yang disimpan pada kondisi AC tetap tinggi hingga akhir periode simpan, sedangkan pada kondisi kamar penurunan viabilitas dimulai pada periode simpan 16 minggu. Benih yang disimpan

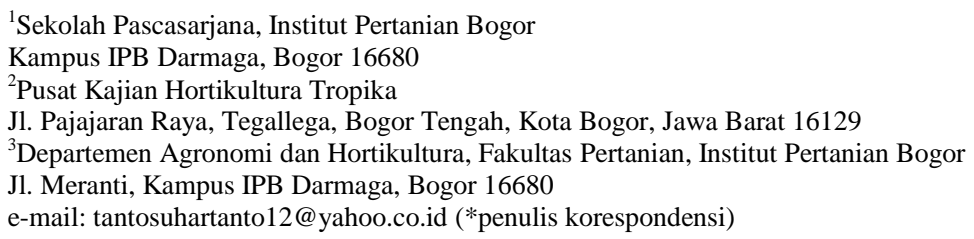


dengan tingkat KA awal sebesar 12-14\% lebih cepat mengalami penurunan viabilitas mulai periode simpan 18 minggu dibandingkan dengan benih dengan KA awal 8-10\%. Hasil penelitian juga menunjukkan terdapat korelasi yang erat antara pola kemunduran benih pada pengusangan cepat dan penyimpanan aktual, sehingga model pendugaan vigor daya simpan (y) berdasarkan waktu pengusangan (x) dapat disusun dengan persamaan $y=a+b \exp ^{c x}$. Simulasi pendugaan vigor daya simpan dengan nilai konstanta $a, b$, dan $c$ serta input waktu pengusangan dapat menduga vigor daya simpan benih selama penyimpanan aktual.

Kata kunci: alat IPB 77-1 MM, alat IPB 77-1 MMM, pengusangan cepat, penyimpanan benih, simulasi

\section{PENDAHULUAN}

Pepaya (Carica papaya L.) merupakan salah satu komoditas buah tropika yang populer di Indonesia. Berbagai varietas unggul telah dihasilkan. Agar varietas unggul tersebut dapat sampai ke petani guna meningkatkan produksi dan kualitas buah, maka ketersediaan benih bermutu perlu dijaga. Produksi dan kualitas buah tidak saja berasal dari keunggulan varietas, namun penggunaan benih yang bermutu merupakan salah satu kunci keberhasilan budidaya pepaya.

Mutu benih yang rendah merupakan kendala utama dalam upaya peningkatan produksi. Wahyuni et al. (2015) menyatakan bahwa produsen benih harus mengetahui periode kapan benih mengalami kemunduran sehingga tidak layak lagi untuk dijual. Informasi mutu benih diprodusen hanya ada pada awal produk dikemas dan sebelum didistribusikan. Hingga saat ini informasi terkait mutu benih saat akan ditanam atau selama periode simpan dilakukan melalui percobaan penyimpanan benih pada kondisi aktual, tetapi kegiatan tersebut dinilai kurang efisien dari segi waktu dan biaya.

Metode pengusangan cepat dilakukan pertama kali oleh Delouche pada tahun 1971 dengan memberikan perlakuan fisik dengan suhu $41{ }^{\circ} \mathrm{C}$ dan $\mathrm{RH} \approx 100 \%$ selama 72 jam dalam inkubator (Copeland dan McDonald, 2001). Sadjad tahun 1974 mengembangkan metode pengusangan cepat secara kimiawi yaitu dengan etanol, dan dirancang alat pengusangan cepat dengan uap etanol pada tahun 1977 yang diberi kode IPB 77-1. Alat IPB 77-1 terus mengalami modifikasi untuk meningkatkan efektifitas pengusangan diantaranya IPB 77-1 M oleh Sadjad pada tahun 1992 dan IPB 77-1 MM oleh Suhartanto pada tahun 1994 (Terryana et al., 2015).
Tahun 2013 alat IPB 77-1 MM dimodifikasi menjadi IPB 77-1 MMM yang dikhususkan sebagai alat pengusangan cepat secara fisik, yaitu dengan uap panas. Penelitian berkaitan dengan pengujian efektifitas MPC IPB 77-1 MMM sebagai alat pendugaan vigor daya simpan benih belum ada sampai saat ini.

Penelitian ini dilaksanakan untuk membandingkan efektifitas pengusangan cepat secara kimiawi dengan alat IPB 77-1 MM dan secara fisik dengan alat IPB 77-1 MMM pada benih papaya. Metode pengusangan cepat yang efektif diharapkan dapat menghasilkan pola penurunan viabilitas benih yang bisa digunakan untuk membuat pendugaaan vigor daya simpan benih pepaya. Tujuan penelitian ini adalah untuk membandingkan metode pengusangan cepat yang efektif antara fisik dengan kimia serta mempelajari pola penurunan viabilitas benih selama penyimpanan aktual pada kondisi simpan kamar dan AC dengan tiga tingkat kadar air awal $(8-10 \%, 10-12 \%$, dan $12-14 \%)$ selama 20 minggu, dan membangun model vigor daya simpan benih pepaya.

\section{BAHAN DAN METODE}

Penelitian ini dilaksanakan di Laboratorium Ilmu dan Teknologi Benih, Departemen Agronomi dan Hortikultura, Institut Pertanian Bogor pada bulan Oktober 2015 sampai Mei 2016. Bahan yang digunakan adalah buah pepaya varietas Callina hasil pemeraman dengan tingkat kematangan 8090\% (Murniati et al., 2007). Seluruh benih dalam buah dibersihkan dari sarkotesta menggunakan abu gosok dan dibilas hingga bersih (Suhartanto et al., 2011). Benih selanjutnya dikeringanginkan sesuai dengan kadar air percobaan yaitu $8-10 \%$ selama tiga hari, 10- 
$12 \%$ selama dua hari dan $12-14 \%$ selama satu hari pada suhu $26-30{ }^{\circ} \mathrm{C}$ dan $\mathrm{RH} 45-65 \%$.

\section{A. Efektivitas Metode Pengusangan Cepat secara Fisik dan Kimiawi Benih Pepaya}

\section{A.1. Pengusangan Cepat Benih Pepaya secara Fisik dengan Alat IPB 77-1 MMM.}

Rancangan percobaan disusun menggunkan rancangan acak lengkap tersarang pada waktu pengusangan. Waktu pengusangan terdiri atas 11 taraf $(0 \times 5,1 \times 5$, $2 \times 5,3 \times 5,4 \times 5,5 \times 5,6 \times 5,7 \times 5,8 \times 5,9 \times 5$ dan $10 \times 5$ menit) yang diulang sebanyak empat kali. Tiap ulangan terdiri atas 50 butir benih. Angka pertama menunjukkan frekuensi pengusangan dan angka kedua menunjukkan waktu pengusangan. Peubah vigor daya simpan yang diamati adalah daya berkecambah setelah pengusangan cepat (VDS ${ }_{\mathrm{PC}}^{\mathrm{DB}}$ ). Sebanyak 50 butir benih yang akan diusangkan direaktivasi dengan cara dilembabkan diantara tiga lembar kertas selama empat hari. Benih lembab dimasukkan ke dalam tabung dalam ruang deraan. Pengusangan cepat benih menggunakan uap panas yang berasal dari proses pemanasan $\pm 900 \mathrm{~mL}$ air yang dialirkan ke dalam ruang deraan. Suhu dan RH ruang deraan mencapai konstan selama 90 menit dengan kisaran suhu $50-60{ }^{\circ} \mathrm{C}$ dan $\mathrm{RH}>90 \%$.

\section{A.2. Pengusangan Cepat Benih Pepaya secara Kimiawi dengan Alat IPB 77-1 MM.}

Rancangan percobaan disusun menggunakan rancangan acak lengkap tersarang pada waktu pengusangan. Waktu pengusangan terdiri atas 8 taraf $(0 \times 20,1 \times 20$, $2 \times 20,3 \times 20,4 \times 20,5 \times 20,6 \times 20$ dan $7 \times 20$ menit) yang diulang sebanyak empat kali. Angka pertama menunjukkan frekuensi pengusangan dan angka kedua menunjukkan waktu pengusangan. Peubah vigor daya simpan yang diamati adalah daya berkecambah setelah pengusangan cepat ( VDS $\mathrm{PC}$ ). Pengusangan cepat benih dilakukan dengan menggunakan uap etanol $96 \%$. Uapdalam ruang deraan berasal dari proses pemanasan $\pm 60 \mathrm{~mL}$ etanol yang kemudian dialirkan ke dalam ruang deraan. Benih hasil reaktivasi didera dengan uap etanol sesuai dengan waktu pengusangan yang telah ditentukan.

Data dianalisis dengan uji $\mathrm{F}$, apabila berpengaruh nyata dilakukan uji lanjut Duncan Multiple Range Test (DMRT) pada taraf $\alpha=$ $5 \%$. Metode pengusangan cepat yang efektif dipilih berdasarkan metode yang menghasilkan penurunan nilai daya berkecambah (DB) sebesar $40 \%$ dari viabilitas awal dengan waktu yang lebih singkat. Penentuan batas penurunan DB didasari oleh tingkat kelayakan benih sebagai bahan tanam dengan nilai daya berkecambah sebesar $60 \%$.

\section{B. Penurunan Viabilitas Benih Selama Penyimpanan Aktual}

Penyimpanan dan pengujian benih dilakukan dengan tujuan untuk mempelajari perilaku benih pepaya yang disimpan pada ruang kamar (suhu $28-30^{\circ} \mathrm{C}$, RH 75-78\%) dan ruang $\mathrm{AC}$ (suhu $18-20{ }^{\circ} \mathrm{C}$, RH 51-60\%) selama 20 minggu. Rancangan percobaan disusun dengan rancangan acak lengkap tersarang pada kondisi ruang penyimpanan (ruang kamar dan AC) dengan perlakuan kadar air awal benih (8$10 \%, \quad 10-12 \%$, dan 12-14\%). Kombinasi perlakuan diulang sebanyak empat kali ulangan. Satu satuan percobaan terdiri atas 50 benih yang dikemas dengan aluminium foil. Pengamatan dilakukan pada periode simpan 0 , $2,4,6,8,10,12,14,16,18$, dan 20 minggu. Peubah vigor daya simpan yang diamati adalah daya berkecambah selama penyimpanan aktual $\left(\mathrm{VDS}_{\mathrm{akt}}^{\mathrm{DB}}\right)$. Data dianalisis dengan uji F, apabila berpengaruh nyata dilakukan uji lanjut DMRT pada taraf $\alpha=5 \%$.

\section{Penyusunan Model Pendugaan Vigor Daya Simpan Benih Pepaya}

\section{C.1. Pembuatan Pola Penurunan Viabilitas Benih.}

Data kemunduran benih hasil pengusangan cepat yang terpilih dan penyimpanan aktual disusun berdasarkan persamaan eksponensial dengan dasar laju penurunan viabilitas benih menggambarkan pola yang non linier. Model pesamaan yang digunakan sebagai berikut:

$\mathbf{y}=\mathbf{a}+\mathbf{b} \exp ^{\mathrm{cx}}$ .(persamaan 1)

Untuk $\mathrm{a}, \mathrm{b}$ dan $\mathrm{c}$ adalah konstanta, $\mathrm{x}$ adalah waktu pengusangan (menit)/periode simpan (minggu) dan y adalah vigor daya 
simpan benih selama pengusangan cepat $\left(\mathrm{VDS}_{\mathrm{PC}}^{\mathrm{DB}}\right) /$ penyimpanan aktual $\left(\mathrm{VDS}_{\mathrm{akt}}^{\mathrm{DB}}\right)$.

\section{C.2. Penyusunan Persamaan untuk Model Pendugaan Vigor Daya Simpan.}

Model pendugaan vigor daya simpan pada setiap tingkat kadar air dan ruang simpan disusun berdasarkan persamaan eksponensial, dengan $\mathrm{x}$ adalah waktu pengusangan (menit) dan y adalah vigor daya simpan benih aktual $\left(\mathrm{VDS}_{\mathrm{akt}}^{\mathrm{DB}}\right)$. Model persamaan pendugaan vigor daya simpan yang akan disusun sebagai berikut:

$$
\operatorname{VDS}_{\text {dugaan }}^{\text {DB }}=\mathbf{a}+\mathbf{b} \exp ^{\mathbf{c x}} \ldots \ldots \ldots . . .(\text { persamaaan } 2)
$$

Pola pendugaan vigor daya simpan (persamaan 2) diawali dengan mencari korelasi antara peubah VDS ${ }_{\mathrm{PC}}^{\mathrm{DB}}$ dengan $\mathrm{VDS}_{\mathrm{akt}}^{\mathrm{DB}}$. Koefisien korelasi sebesar satu mengindikasikan bahwa VDS $S_{\mathrm{PC}}^{\mathrm{DB}}$ dapat menggambarkan $\operatorname{VDS}_{\mathrm{akt}}^{\mathrm{DB}}$.

\section{C.3. Verifikasi dan Simulasi Model Vigor Daya Simpan.}

Verifikasi bertujuan untuk menilai kesesuaian output hasil model dengan hasil aktual yang dilakukan secara deskriptif dan uji statistik. Verifikasi secara deskriptif dilakukan dengan membandingkan pola eksponensial dengan diagram pencar melalui masuknya pola dalam standar deviasi sebagai tingkat kesesuaian. Verifikasi dengan uji statistik dilakukan menggunakan uji-t. Apabila nilai $p$ value lebih besar dari nilai $\alpha(0.05)$ maka nilai tengah kedua populasi yang diuji tidak berbeda nyata. Simulasi dilakukan dengan menggunakan persamaan model pendugaan vigor daya simpan dengan input waktu pengusangan cepat (x) dan output vigor daya simpan dugaan (VDS dugaan).

\section{HASIL DAN PEMBAHASAN}

\section{A. Efektivitas Metode Pengusangan Cepat secara Fisik dan Kimiawi Benih Pepaya}

Pengusangan cepat benih secara fisik dilakukan dengan cara memberikan lingkungan ekstrim pada benih dengan suhu dan kelembaban tinggi. Suhu dan kelembaban yang tinggi saling berinteraksi dalam menurunkan viabilitas benih. Penurunan viabilitas benih akibat pengusangan cepat fisik dapat disebabkan oleh berbagai faktor, diantaranya terjadinya peningkatan kandungan lipid peroksida pada benih padi (Tilebeni dan Golpayegani, 2011), peningkatan laju respirasi pada benih kedelai (Tian et al., 2008), denaturasi protein pada benih padi dan kapas (Kapoor et al., 2011; Goel dan Sheoran, 2014), meningkatnya aberasi kromosom pada benih gandum (Menezes et al., 2014), dan terjadinya kerusakan membran sel serta meningkatnya elektrolit pada benih kapas (Nik et al., 2011). Sedangkan penurunan viabilitas benih akibat pengusangan cepat kimia dengan etanol disebabkan oleh perubahan sifat molekul makro yang berpengaruh terhadap penurunan aktivitas enzim, kerusakan membran sel, mitokondria dan organel lainnya yang berperan dalam perkecambahan benih (Saenong, 1986).

Penurunan daya berkecambah benih pepaya setelah diusangkan secara fisik terlihat nyata pada taraf waktu 40 menit. Penurunan viabilitas benih pepaya selama pengusangan fisik cenderung melandai pada awal taraf waktu pengusangan dan menurun tajam setelah diusangkan selama 40 menit hingga akhir periode pengusangan (Tabel 1). Hasil penelitian Syarifah et al. (2014) pada benih kedelai dengan viabilitas awal $\approx 100 \%$ menunjukkan viabilitas benih menurun secara tajam setelah benih diusangkan selama 15 menit.

Penurunan persentase daya berkecambah dengan metode pengusangan cepat kimiawi mulai terjadi pada benih yang diusangkan selama 140 menit. Hingga akhir taraf pengusangan viabilitas benih masih tinggi, yaitu sebesar $76.7 \%$ (Tabel 1). Taraf waktu pengusangan yang digunakan belum mampu menurunkan viabilitas benih sebesar $40 \%$ yang menjadi dasar pemilihan metode pengusangan. Hal ini menunjukkan bahwa benih pepaya cukup tahan terhadap deraan uap etanol. Rosida et al. (2015) menunjukkan bahwa lima lot benih kubis yang diusangkan dengan cara perendaman dalam etanol $20 \%$ selama 120 menit memiliki viabilitas antara $30.0-0.0 \%$. 
Tabel 1. Nilai tengah daya berkecambah (\%) benih pepaya selama pengusangan cepat secara fisik dan kimia $\left(V_{D S}^{\mathrm{DB}}\right)$

\begin{tabular}{|c|c|c|c|c|c|c|c|c|c|c|}
\hline Perlakuan & \multicolumn{10}{|c|}{ Waktu Pengusangan (menit) } \\
\hline \multirow{2}{*}{ MPC Fisik } & 0 & 5 & 10 & 15 & 20 & 25 & 30 & 35 & 40 & 45 \\
\hline & $96.5 \mathrm{ab}$ & $97.0 \mathrm{ab}$ & $98.0 \mathrm{a}$ & $92.0 \mathrm{ab}$ & $94.5 \mathrm{ab}$ & $92.5 \mathrm{ab}$ & $93.5 \mathrm{ab}$ & $91.0 \mathrm{ab}$ & $42.5 \mathrm{c}$ & $44.7 \mathrm{c} 18.0 \mathrm{~d}$ \\
\hline \multirow{2}{*}{ MPC Kimia } & 0 & 20 & 40 & 60 & 80 & 100 & 120 & 140 & & \\
\hline & $99.0 \mathrm{a}$ & $96.5 \mathrm{ab}$ & $94.5 \mathrm{ab}$ & $.0 \mathrm{ab}$ & $92.0 \mathrm{abc}$ & $90.5 \mathrm{bc}$ & $85.0 \mathrm{c}$ & $76.7 \mathrm{~d}$ & & \\
\hline
\end{tabular}

Keterangan: MPC = metode pengusangan cepat, angka yang diikuti dengan huruf yang sama pada baris yang sama tidak berbeda nyata berdasarkan uji DMRT pada taraf $\alpha=5 \%$.

Benih dengan kandungan lipid tinggi berpotensi mengalami proses kemunduran lebih cepat (Tubic et al., 2011). Kandungan lipid pada benih pepaya tergolong tinggi, yaitu sebesar 29.2\%. Struktur lipid pada benih pepaya memiliki indeks kestabilan oksidatif cukup lama (77.97 jam). Indeks kestabilan oksidatif merupakan peubah yang berkaitan dengan resistensi lemak teroksidasi. Indeks kestabilan oksidatif benih pepaya 6.3-7.8 kali lebih lama dibandingkan benih kedelai dan bunga matahari (Malacrida et al., 2011). Hal ini diduga menyebabkan viabilitas benih cenderung stabil hingga pertengahan waktu pengusangan dan menurun menjelang akhir pengusangan.

Metode pengusangan cepat benih pepaya yang terpilih adalah metode pengusangan cepat secara fisik. Metode pengusangan secara fisik mampu menurunkan viabilitas benih lebih cepat dalam waktu yang singkat sehingga metode ini dinilai lebih efektif dan efisien untuk benih pepaya.

\section{B. Penurunan Viabilitas Benih selama Penyimpanan Aktual}

Faktor tunggal ruang simpan berpengaruh nyata pada periode simpan 0,8 , 16, 18, dan 20 minggu, sedangkan faktor tingkat KA awal berpengaruh nyata pada periode $0,6,18$ dan 20 minggu. Secara umum, benih pepaya yang disimpan pada ruang kondisi kamar mulai mengalami kemunduran pada periode simpan 16 minggu, sedangkan benih yang disimpan pada ruang $\mathrm{AC}$ cenderung stabil hingga akhir periode simpan. Benih yang disimpan dengan tingkat KA awal sebesar $12-14 \%$ lebih cepat mengalami penurunan. Penurunan DB pada tingkat KA awal $12-14 \%$ mulai terjadi saat periode simpan 18 minggu. Namun, viabilitas benih masih tergolong tinggi pada ketiga tingkat KA awal hingga periode simpan 20 minggu dengan kisaran DB sebesar 81-89\% (Tabel 2).

\section{Penyusunan Model Pendugaan Vigor Daya Simpan Benih Pepaya}

\section{C.1. Pola Perilaku Daya Berkecambah selama Pengusangan Cepat secara Fisik dan Penyimpanan Aktual.}

Perilaku daya berkecambah benih selama pengusangan cepat (VDS $\left.S_{\mathrm{PC}}^{\mathrm{DB}}\right)$ didapatkan melalui persamaan $\mathrm{y}=100.557$ $1.23591 \exp ^{(0.0848072 x)}$, output yang dihasilkan dijadikan sebagai daya berkecambah dugaan. Nilai DB dugaan selanjutnya dilakukan uji kesesuaian dengan nilai DB aktual secara deskriptif menggunakan kurva (Gambar 1).

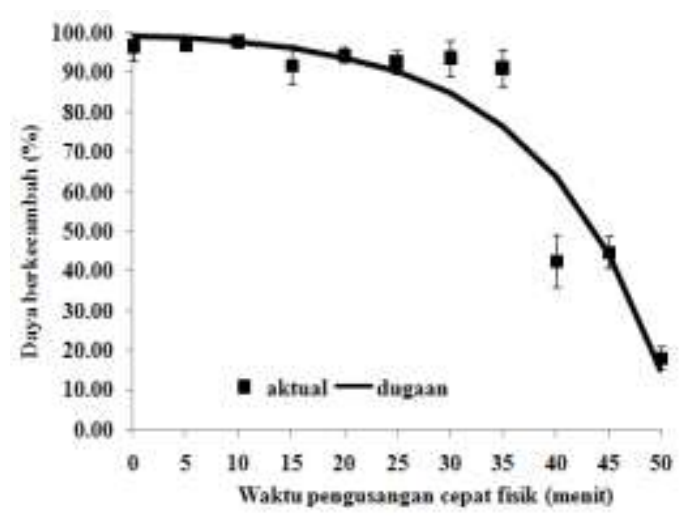

Gambar 1. Pola penurunan daya berkecambah benih selama pengusangan cepat secara fisik. 
Tabel 2. Pengaruh ruang simpan dan KA awal terhadap daya berkecambah benih selama penyimpanan aktual (VDS ${ }_{\text {akt }}^{\mathrm{DB}}$ )

\begin{tabular}{|c|c|c|c|c|c|c|c|c|c|c|c|}
\hline \multirow{2}{*}{ Perlakuan } & \multicolumn{11}{|c|}{ Daya Berkecambah Benih pada Periode Simpan (minggu) } \\
\hline & 0 & 2 & 4 & 6 & 8 & 10 & 12 & 14 & 16 & 18 & 20 \\
\hline Ruang Simpan & & & & & &..$\%$ & & & & & \\
\hline Kamar & $96.9 \mathrm{a}$ & $94.8 \mathrm{a}$ & $94.0 \mathrm{a}$ & $94.7 \mathrm{a}$ & $88.3 \mathrm{~b}$ & $93.3 \mathrm{a}$ & $92.3 \mathrm{a}$ & $94.0 \mathrm{a}$ & $79.9 \mathrm{~b}$ & $79.8 \mathrm{~b}$ & $79.8 \mathrm{~b}$ \\
\hline $\mathrm{AC}$ & $94.3 \mathrm{~b}$ & $92.3 \mathrm{a}$ & $94.2 \mathrm{a}$ & $95.8 \mathrm{a}$ & $94.5 \mathrm{a}$ & $94.3 \mathrm{a}$ & $95.5 \mathrm{a}$ & $96.2 \mathrm{a}$ & $87.5 \mathrm{a}$ & $91.5 \mathrm{a}$ & $91.5 \mathrm{a}$ \\
\hline KA Awal (\%) & & & & & &.$\%$ & & & & & $\cdots$ \\
\hline $8-10$ & $97.3 \mathrm{a}$ & $91.0 \mathrm{a}$ & $94.0 \mathrm{a}$ & $99.0 \mathrm{a}$ & $92.8 \mathrm{a}$ & $95.8 \mathrm{a}$ & $95.3 \mathrm{a}$ & $95.5 \mathrm{a}$ & $87.3 \mathrm{a}$ & $89.3 \mathrm{a}$ & $89.3 \mathrm{a}$ \\
\hline $10-12$ & $93.3 \mathrm{~b}$ & $95.1 \mathrm{a}$ & $94.8 \mathrm{a}$ & $93.5 \mathrm{~b}$ & $92.5 \mathrm{a}$ & $92.5 \mathrm{a}$ & $95.3 \mathrm{a}$ & $95.6 \mathrm{a}$ & $82.5 \mathrm{a}$ & $87.0 \mathrm{ab}$ & $87.0 \mathrm{ab}$ \\
\hline $12-14$ & $96.3 \mathrm{ab}$ & $94.3 \mathrm{a}$ & $93.5 \mathrm{a}$ & $93.3 \mathrm{~b}$ & $89.0 \mathrm{a}$ & $93.3 \mathrm{a}$ & $91.3 \mathrm{a}$ & $94.0 \mathrm{a}$ & $81.4 \mathrm{a}$ & $80.8 \mathrm{~b}$ & $80.8 \mathrm{~b}$ \\
\hline KK & 3.09 & 6.13 & 4.99 & 3.40 & 5.93 & 3.16 & 5.08 & 4.93 & 8.31 & 8.09 & 8.09 \\
\hline
\end{tabular}

Keterangan: Angka yang diikuti dengan huruf yang sama pada kolom yang sama tidak berbeda nyata berdasarkan uji DMRT pada taraf $\alpha=5 \%$.

Pola perilaku kemunduran benih melalui peubah daya berkecambah hasil dugaan secara dominan sesuai dengan hasil aktual berdasarkan masuknya nilai selang standar deviasi pada setiap titik pengamatan. Uji kesesuaian dengan uji-t menunjukkan nilai $P$-value sebesar 1.00. Hal ini menunjukkan bahwa daya berkecambah hasil dugaan tidak berbeda nyata dengan hasil aktual. Dari kedua uji kesesuaian dapat disimpulkan bahwa model persamaan yang diperoleh mampu menggambarkan pola perilaku kemunduran viabilitas benih secara aktual. Perilaku penurunan daya berkecambah pada setiap perlakuan KA awal dan ruang simpan selama penyimpanan aktual didapatkan berdasarkan persamaan 1 (Tabel 3). Nilai DB dugaan selanjutnya dilakukan uji kesesuaian dengan nilai DB aktual secara deskriptif dan statistik.

Verifikasi perilaku daya berkecambah benih pepaya selama penyimpanan secara deskriptif menunjukkan adanya kesesuaian data hasil aktual dan dugaan (Gambar 2). Uji kesesuaian model secara statistik menunjukkan nilai $P$-value pada perlakuan KA awal 8-10\% ruang simpan AC adalah 1.00, KA awal 10$12 \%$ ruang simpan $\mathrm{AC}(P$-value $=0.94), \mathrm{KA}$ awal $12-14 \%$ ruang simpan $\mathrm{AC}$ ( $P$-value $=$ $0.91)$, KA awal $8-10 \%$ ruang simpan kamar $(P$-value $=0.68), \mathrm{KA}$ awal $10-12 \%$ ruang simpan $\operatorname{kamar}(P$-value $=1.00)$, dan KA awal $12-14 \%$ ruang simpan kamar $(P$-value $=1.00)$. Dari kedua uji kesesuaian dapat disimpulkan bahwa model persamaan yang diperoleh mampu menggambarkan pola perilaku kemunduran viabilitas benih secara aktual.

Benih yang disimpan pada ruang kamar memiliki viabilitas yang rendah dibandingkan pada ruang AC. Viabilitas benih yang disimpan pada ruang kamar dengan KA awal $12-14 \%$ mengalami penurunan paling cepat. Hal ini sesuai dengan kaidah Harrington yang mana setiap kenaikan $1 \%$ kadar air benih (KA 5-14\%) dan kenaikan suhu $5{ }^{\circ} \mathrm{C}$ (suhu $0-50{ }^{\circ} \mathrm{C}$ ) akan mengurangi setengah daya hidup benih (Copeland dan McDonald, 2001).

Tabel 3. Model persamaan daya berkecambah benih selama penyimpanan aktual (VDS ${ }_{\mathrm{akt}}^{\mathrm{DB}}$ )

\begin{tabular}{ll}
\hline \multicolumn{1}{c}{ Perlakuan } & \multicolumn{1}{c}{ Persamaan 1 } \\
\hline KA awal 8-10\% ruang simpan kamar & $\mathrm{y}=95.65-0.0100003 \exp ^{(0.383255 \mathrm{x})}$ \\
KA awal 10-12\% ruang simpan kamar & $\mathrm{y}=94.46-0.000000170039 \exp ^{(0.928297 \mathrm{x})}$ \\
KA awal 12-14\% ruang simpan kamar & $\mathrm{y}=97.01-2.04756 \exp ^{(0.131874 \mathrm{x})}$ \\
KA awal 8-10\% ruang simpan AC & $\mathrm{y}=96.84-0.000637684 \exp ^{(0.50 \mathrm{x})}$ \\
KA awal 10-12\% ruang simpan AC & $\mathrm{y}=94.33-0.0000013746 \exp ^{(0.766988 \mathrm{x})}$ \\
KA awal 12-14\% ruang simpan AC & $\mathrm{y}=94.24-0.0000744441 \exp ^{(0.582433 \mathrm{x})}$ \\
\hline
\end{tabular}

Keterangan: $\mathrm{y}=$ daya berkecambah, $\mathrm{x}=$ periode simpan (minggu) 

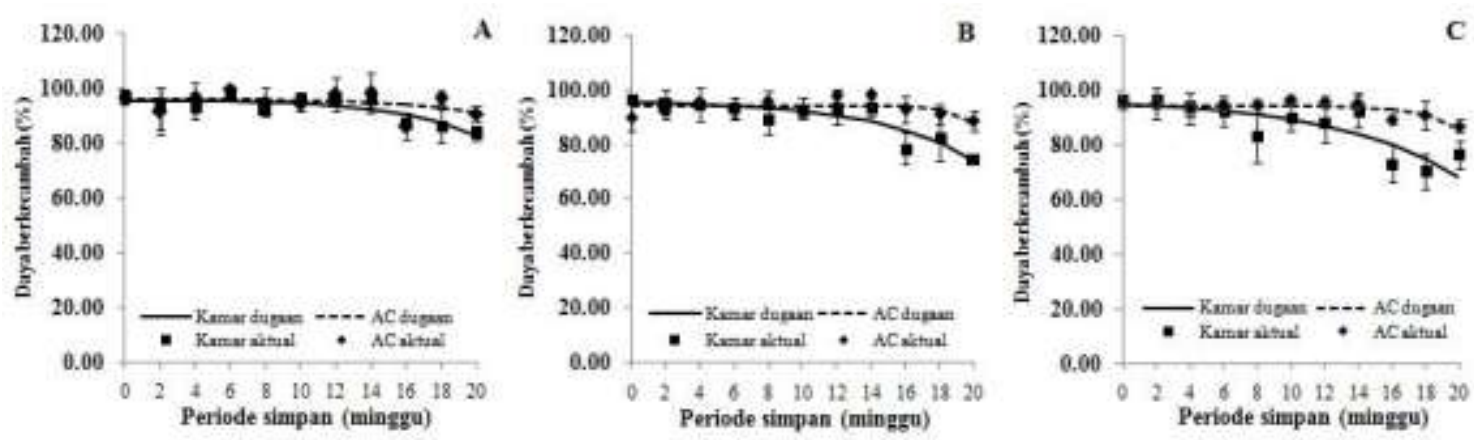

Gambar 2. Pola penurunan daya berkecambah benih pepaya aktual dan dugaan selama penyimpanan pada kedua ruang simpan dengan KA awal A. 8-10\%; B. 10-12\%; dan C. 12-14\%.

\section{C.2. Penyusunan Persamaan untuk Model Pendugaan Vigor Daya Simpan.}

Hasil analisis korelasi menunjukkan bahwa terdapat hubungan yang erat antara daya berkecambah benih hasil pengusangan cepat (VDSPC) dan penyimpanan aktual $\left(\mathrm{VDS}_{\mathrm{akt}}^{\mathrm{DB}}\right)$ pada seluruh kombinasi perlakuan (Tabel 4). Berdasarkan hal tersebut model pendugaan vigor daya simpan $\left(\mathrm{VDS}_{\text {dugaan }}^{\mathrm{DB}}\right)$ berdasarkan waktu pengusangan dapat disusun berdasarkan analisis regresi eksponensial (persamaan 2). Data hasil analisis korelasi dan persamaan VDS dugaan disajikan pada Tabel 4.

\section{C.3. Verifikasi dan Simulasi Model Vigor Daya Simpan.}

Verifikasi secara deskriptif menunjukkan bahwa daya berkecambah hasil pendugaan dengan model sesuai dengan hasil percobaan aktual berdasarkan masuknya nilai selang standar deviasi pada setiap titik pengamatan (Gambar 3). Verifikasi dengan uji statistik menunjukkan bahwa nilai $P$-value pada perlakuan KA awal 8-10\% ruang simpan AC adalah 1.00 , KA awal 10-12\% ruang simpan AC $(P$-value $=0.99), \mathrm{KA}$ awal $12-14 \%$ ruang simpan AC $(P$-value $=0.94), \mathrm{KA}$ awal $8-10 \%$ ruang simpan kamar $(P$-value $=1.00), \mathrm{KA}$ awal $10-12 \%$ ruang simpan $\operatorname{kamar}(P$-value $=$ 0.78 ), dan KA awal $12-14 \%$ ruang simpan kamar $(P$-value $=0.71)$ lebih besar dari nilai $\alpha$ (0.05). Hasil kedua uji kesesuaian dapat disimpulkan bahwa model persamaan pendugaan vigor daya simpan mampu menggambarkan pola perilaku kemunduran viabilitas benih secara aktual. Simulasi model pendugaan dilakukan dengan menggunakan nilai konstanta $(\mathrm{a}, \mathrm{b}, \mathrm{c})$ dengan asumsi input waktu pengusangan cepat selama 55 menit setara dengan periode simpan 22 minggu (Tabel 5).

Tabel 4. Hasil analisis korelasi dan persamaan pendugaan vigor daya simpan (VDS dugaan)

\begin{tabular}{lcl}
\hline \multicolumn{1}{c}{ Perlakuan } & Koefisien Korelasi & \multicolumn{1}{c}{ Persamaan 2 } \\
\hline KA awal 8-10\% simpan kamar & $1.00^{* *}$ & $\mathrm{y}=96.01-0.109238 \exp ^{(0.0956424 \mathrm{x})}$ \\
KA awal 10-12\% simpan kamar & $1.00^{* *}$ & $\mathrm{y}=96.07-0.680866 \exp ^{(0.0693808 \mathrm{x})}$ \\
KA awal 12-14\% simpan kamar & $0.99^{* *}$ & $\mathrm{y}=97.01-2.04756 \exp ^{(0.0527496 \mathrm{x})}$ \\
KA awal 8-10\% simpan AC & $1.00^{* *}$ & $\mathrm{y}=96.40-0.0609959 \exp ^{(0.0883932 \mathrm{x})}$ \\
KA awal 10-12\% simpan AC & $0.88^{* *}$ & $\mathrm{y}=94.33-0.0000013746 \exp ^{(0.306795 \mathrm{x})}$ \\
KA awal 12-14\% simpan AC & $0.92^{* *}$ & $\mathrm{y}=94.24-0.0000744441 \exp ^{(0.232973 \mathrm{x})}$ \\
\hline
\end{tabular}



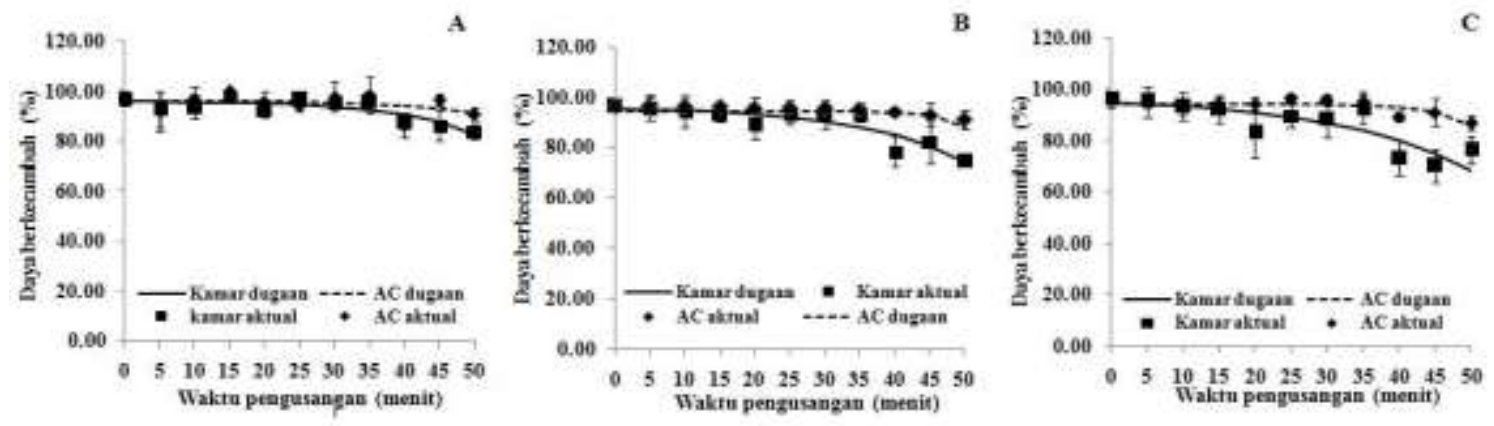

Gambar 3. Verifikasi nilai daya berkecambah dugaan dan aktual pada ruang simpan AC dan kamar dengan kadar air awal A. 8-10\%; B. 10-12\%; dan C. 12-14\%.

Tabel 5. Simulasi pendugaan vigor daya simpan benih

\begin{tabular}{lrrrrrr}
\hline \multirow{3}{*}{ Input Model } & \multicolumn{5}{c}{ Perlakuan Kondisi Simpan dan Kadar Air Awal } \\
\cline { 2 - 7 } & \multicolumn{5}{c}{ Kamar } & \multicolumn{1}{c}{ AC } \\
\cline { 2 - 7 } & $8-10 \%$ & $10-12 \%$ & $12-14 \%$ & $8-10 \%$ & $10-12 \%$ & $12-14 \%$ \\
\hline Waktu usang (menit) & 55.00 & 55.00 & 55.00 & 55.00 & 55.00 & 55.00 \\
Konstanta a & 96.00 & 96.10 & 97.00 & 96.40 & 94.30 & 94.30 \\
Konstanta b & 0.11 & 0.68 & 2.05 & 0.06 & $1.37 \times 10^{-6}$ & $7.44 \times 10^{-5}$ \\
Konstanta c & 0.10 & 0.07 & 0.05 & 0.09 & 0.31 & 0.23 \\
VDS $_{\text {dugaan }}^{\text {DB }}(\%)$ & 75.00 & 65.20 & 59.90 & 88.50 & 65.10 & 66.90 \\
\hline
\end{tabular}

\section{KESIMPULAN}

Hasil yang dapat disimpulkan dari percobaan ini adalah metode pengusangan cepat terpilih adalah metode pengusangan secara fisik selama 40 menit dengan alat IPB 77-1 MMM. Viabilitas benih yang disimpan pada kondisi $\mathrm{AC}$ tetap tinggi $(\mathrm{DB}=94.3 \%)$ hingga akhir periode simpan $(\mathrm{DB}=91.5 \%)$, sedangkan pada kondisi kamar penurunan viabilitas dimulai pada periode simpan 16 minggu. Benih yang disimpan dengan tingkat KA awal 12-14\% lebih cepat mengalami penurunan viabilitas mulai periode simpan 18 minggu dibandingkan benih dengan KA awal $8-10 \%$.

Vigor daya simpan benih dapat diduga melalui pengusangan cepat secara fisik berdasarkan persamaan eksponensial $\mathrm{y}=\mathrm{a}+\mathrm{b}$ $\exp ^{\mathrm{cx}}$ dengan nilai konstanta $\mathrm{a}, \mathrm{b}$ dan c sebesar 96.01, 0.11, dan 0.10 untuk KA awal 8-10\% ruang simpan kamar, 96.07, 0.68, dan 0.07 untuk KA awal 10-12\% ruang simpan kamar, 97.01, 2.05, dan 0.05 untuk KA awal 12-14\% ruang simpan kamar, 96.40, 0.06, dan 0.09 untuk KA awal $8-10 \%$ ruang simpan $\mathrm{AC}$,
$94.33,1.37 \times 10^{-6}$, dan 0.31 untuk KA awal 10$12 \%$ ruang simpan $\mathrm{AC}, 94.24,7.44 \times 10^{-5}$, dan 0.23 untuk KA awal $12-14 \%$ ruang simpan AC.

\section{DAFTAR PUSTAKA}

Copeland, L.O., M.B. McDonald. 2001. Principles of Seed Science and Technology. 4th Ed. Kluwer Academic, Massachusetts.

Goel, A., S.I Sheoran. 2014. Seed soluble protein pattern of cotton (Gossypium hirsutum L.) under the influence of accelerated ageing. Annals of Agri-Bio Research. 19(3): 441-443.

Kapoor, N., A. Arya, A. Siddiqui, H. Kumar, A. Amir. 2011. Physiological and biochemical changes during seed deterioration in aged seeds of rice (Oryza sativa L.). Am. J. Plant. Physiol. 6 (1): 28-35. 
Malacrida, C.R., M. Kimura, N. Jorge. 2011. Characterization of a high oleic oil extracted from papaya (Carica papaya L.) seeds. Ciênc. Tecnol. Aliment. Campinas. 31(4): 929-934.

Menezes, V., S.J. Lopes, S.B. Tedesco, F.A. Henning, H.D. Zen, L.M. Mertz. 2014. Cytogenetic analysis of wheat seeds submitted to artificial aging stress. Journal of Seed Sci. 36(1) : 71-78.

Murniati, E., M. Sari, E. Fatimah. 2008. Pengaruh pemeraman buah dan periode simpan terhadap viabilitas benih pepaya (Carica papaya L.). Bul. Agron. 36(2): 139-145.

Nik, M.S.M., G.H. Tilebeni, K.F.G.H. Jae, M. Sadeghi, E. Sedighi. 2011. Free fatty acid and electrical conductivity changes in cotton seed (Gossypium hirsutum) under seed deteriorating conditions. Int. J. Agric. Sci. Iran. 1: 62-66.

Rosida, A,. M. Sari, M.R. Suhartanto. 2015. Pendugaan vigor daya simpan benih kubis (Brassica oleracea L. var. capitata) menggunakan metode pengusangan cepat dengan etanol. J. Hort. Indonesia. 6(3) : 152-160.

Saenong, S. 1986. Kontribusi vigor awal terhadap daya simpan benih jagung (Zea mays L.) dan kedelai (Glycine max L. Merr.). [Disertasi]. Institut Pertanian Bogor. Bogor.

Suhartanto, M.R., R.R. Wulandari, S. Sujiprihatin. 2011. Benih pepaya (Carica papaya L.): bersifat ortodoks ataukah intermediet?. Seminar Nasional Perhimpunan Hortikuktura Indonesia (PERHORTI). Kemandirian Produk Hortikultura untuk Memenuhi Pasar Domestik dan Ekspor. 23-24 November 2011. Bandung

Syarifah, M., M.R. Suhartanto, A. Qadir. 2014. Kemunduran benih akibat pengusangan cepat menggunakan alat IPB 77-1 MM dan penyimpanan alami. Bul. Agron. 2(1): 1-10.

Terryana, R.T., M.R. Suhartanto, A. Qadir 2015. Alat pengusang cepat IPB 77-1 MM untuk penapisan vigor daya simpan benih kedelai. Penelitian. Pert. Tan. Pangan. 34(3): 229-236.

Tian, X., S. Song, Y. Lei. 2008. Cell death and reactive oxygen species metabolism during accelerated ageing of soybean axes. Russ. Jour. Plant Physiol. 5(1): 33-40.

Tilebeni, G.H., Golpayegani. 2011. Effect of seed ageing on physiological and biochemical changes in rice seed (Oryza sativa L.). Int. J. Agric. Sci. 1: 138-143.

Tubic, S.B., M. Tatic, V. Dordevic, Z. Nikolic, J. Subic, V. Dukic. 2011. Changes in soybean as affected by accelerated and natural aging. Rom. Biotechnol. Letters. 16(6): 6740-6747.

Wahyuni, A., M.R. Suhartanto, A. Qadir. 2015. Model dinamik vigor daya simpan benih kedelai pada penyimpanan terbuka. Penelitian. Pert. Tan. Pangan. 34(3): 219-228. 